\title{
流体力学における計算機の利用* Utilization of Computer for Fluidynamics
}

\author{
安喜隆 幸** \\ Takayuki AKI
}

\section{1. はじめがき}

流体力学に㧍ける計算機の利用という題目は，乙れ 一つでも大きなシンポジゥムを維持できる。つまり流 体力学の展望規模はマッ八数とレイノルズ数の面でと らえただけであ，その広がりに驚くべきあのをあって いる. まして宇宙飛しょうで遭遇するようなパラメタ を次々と座標軸に加えると, 展望の次元も増加し関連 性む複雑となる。 それは個人の努力程度では到底覆い つくせない対象である，そこで，題目に恥じるととに はなるが，筆者の経験を中心とした話題を提供し，流 体力学における計算機の利用の一断面をみるというこ とにしたい，それであなお，筆者の負担能力をてえる という勝手な理由のもとに割愛した話題すある。 それ らについて, 後日会員諸兄のどなたか話題提供を試み て下さることに期待を加ているととを申しそえさせ ていただきます.

\section{2. 流体力学における計算機の利用一鈍頭問題}

アポロ・カプセルのように，飛行方向にむかって大 きな先端曲率をあつ物体は鈍頭であるといわれる. 衛 星または月軌道加ら大気圈へ再突入し直接的に地表到 達する物体は，突入径路上で遭遇する熱的負荷軽娍の ため鈍頭に設計される，突入径路上で，速度は減少し 大気密度が増加するから飛行条件は時々変化してい る. しかし，多くの場合，各時刻飞対応する条件にお いての定常流れを仮定した解析によって問題の解決が 計られている. この定常流解析方法が意味を持つの は, 飛行条件の時間的変化に対して流れ場の中におけ る力学的あるいは物理化学的変化の䌅和時間か十分に 短かい場合である。人間宇宙飛しょう体の再突入径路 の大部分でこの条件は（実用的精度内で）満たされて いる. とうして，非定常性に基づく困難は一応回避で きるとしても，稀薄流から連続流にわたる広い範团の 解析を必要とさせる事情は変わらない，また鈍頭が選 ばれた結果，物体前面に怙りる気体王縮は化学的活性 化を促し，この影響が後流に著しく及んでくる. 通信 や追跡汇関係をむつ電磁波減衰は流れの中における電

\footnotetext{
* 昭和 46 年 10 月 28 日原稿受理

** 航空宇宙技術研究所
}

子密度分布，したがって電離反応を無視しては考えら れない，第 1 図は展型的鈍頭高速飛行体まわりの流れ 模様である. 物体 (球) の前方に衛撃波が形成される のと，長い伴流が続くのが特徴である．熱的負荷のみ が問題であれば，先端付近が最大であるのでその領域 のみの考察であ実用性はある. 通信, とくにその途絶 (black out) の問題を考察するならば, 通常, アンテ ナが設置される先端に引き続く物体上のプラズマ流れ が解析されねばならない，さらに追跡におりるレーダ 断面積を考えようとするならば，伴流領域も考察の対 象としなければならない，伴流領域における電子密度 が無視し得る程度にまで小さくなる長さが物体半径の $10^{3}$ 倍をこえることも珍しくない，結局，高速飛行体 の流れ場は解かれるべき空間範囲もまた広いととを要 請される. 目下のとてろ，てのような流れ全域を一つ の問題として解ぐととのできる方法原理は見つかっ ていない. そこで, 常識的に選ばれるのは，

（1）鈍頭の先端付近の流れ

（2）（1）に続く物体壁に沿う流れ

(3) 伴流**

のように分割し，解を接続する方法である（2）と （3）における接続には1 段前の流れ場の解から得られ

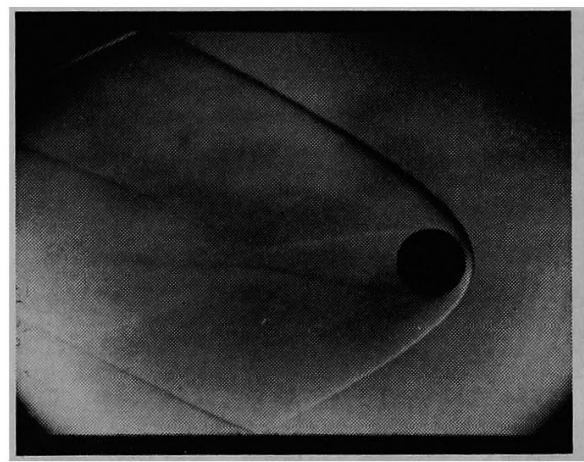

第 1 图 球の自由飛行実験シュリーレン写真 空気中360 Torr, 速度 $0.96 \mathrm{~km} / \mathrm{sec}$ において锶測され た. 離脱衝撃波、顠部をすつ伴流，浮動衝撃波などがよ くみられる. (東大・宇宙研 小口教授のご好意による)

* 一組の基碟方程式と境界条件のすとに全領域か解ける という意味においてである.

**多くの場合，近接領域と遼隔領域に分割して解析され る.たとえぱ第 1 図の 䫫部より上流と下流が 分割され る. 


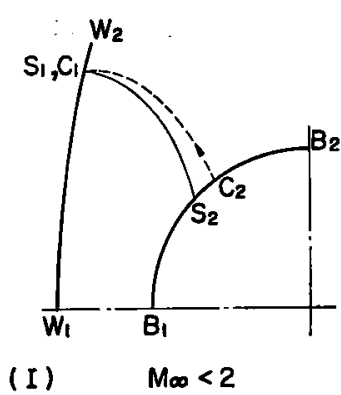

(II)

$$
M_{\infty}<2
$$

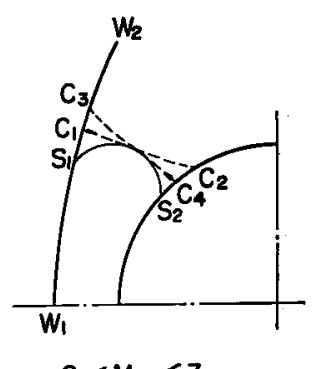

$2<M_{\infty}<3$

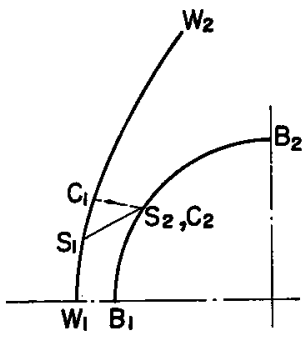

$3<M_{\infty}$

第 2 図 鈍頭先端付近の流れ場のスケッチ

飛行マッ八数 $\left(M_{\infty}\right)$ 加増加するにつれ，墅等波面 $\left(W_{1}-W_{2}\right)$ は物体表面 $\left(B_{1}-B_{2}\right)$ に近つく. $S_{1}-S_{2}$ は音速 線， $C_{1}-C_{2}, C_{3}-C_{4}$ は極限特性線である. (I) は球，(II) は円柱における流れ場である.

る条件が用いられる。実際にはとれが大変な労力と広 い範囲にわたる流体力学の素養を要求する仕事にな る. 労力のほうについていえば, 最新鋭の電子計算機 によってあ数十時間を必要とするてとは珍しくあな い.また素養のほうについていえば, 化学反岕と流れの 干渋に関する知識はどの場合においてい必要である. 衙撃層の解析に抢いては気体中の反応が主役を演ずる が, 境界層においては物体壁の触媒性, 物質付加の効 果あ入ってくる. また乱流領域があれば，乱れと化学 的エネルギの相互作用を考虑した乱流理論によらねば ならない.とうした化学反応による効果の総和によっ て，物体への熱伝達あるいは電磁波との干涉が支配さ れる. 反応を伴わない古典的粒子にたいする流体力学 ですら今日なお末解明の分野があり,とくに稀薄流, 乱 流などと一ロで呼ばれている分野では世界観ないし指 導原理に抽ける混沌をいまだ抜けきってはいない，乙 うした背景のままでの高速飛行体まわりの流れの解析 には，非常な困難があるてとを認めていただけよう.

ここでは，当面の解決策が物体先端付近の流れの解 析任始まることを基に，それを鈍頭問題と呼びそこで の事情がどのようにあるかを調べてみよう．その中で 流体力学と電子計算機の利用の問題を考察するととに しょう.

\section{3. 逆解法}

鈍頭問題はその領域が垔音速であるため, 解析上遭 遇する数字的困難で特徽つけられる. その本質的性格 は非粘性連続流の解析方法を調へることで十分に理解 される.

解析法を方法論で分類すると

（1）衛軗波形状を与え，その背後の流れ場を解 き, 物体形状を最終的に求める,

（2）物体形状を与えて流れ場を解く あののいずれかれなる.（1）に属する手法は，それが
解析的であろうと数值的であろうと，逆(または間接)

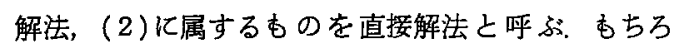
ん，いずれ扎いても一樣流条件*之物体壁上条件は 与えておく.

それぞれの解法に立ち入る前に，流れ場の状況を対 称流れを例にとって述へておく，対称流れの代表とし て，2 次元円柱まわりのそれと，軸対称である球まわ りのそれとを取りあげる(第 2 図). 物体の前方澊撃 波が形成される．対称中心近くで衝撃波を通過した粒 子治強い王縮を経験しながら物体表面に近つくく，対称 中心上の粒子は物体面に達したところで速度 0 (よど み点または線）となったのち物体表面に沿って流れ る. この粒子は次第に加速を受け物体面上のある所で 音速に達する. 対称中心加ら離れて衝壁波面を通過す る粒子は物体面に到達するととてそしないが，すなわ ち速度 0 を経験しないととを除けば大体類似の経過を たどって超音速になる．衝撃波面上のあるところで粒 子速度が局所音速に等しいととが标てる.したがって 衝綮波面上のある点と物体上のある点との間を結んで 連続な音速線（または面）を描くことができる、つま り，衙撃波，対称中心，物体表面，音速面で囲まれる 領域は亜音速となっている，音速面，衝撃波形状はマ ッ八数と気体比熱比の関数であるてとは確かだがあら かじめわかってはいない，また衙撃波と物体間の距離 屯未知である，与えられた一様流条件と物体形状につ いて，てれらの未知量を求めることが問題である. 物 体面上条件は今の場合唯一で，流れが物体表面に沿う ことを要請するだけである**.

文章で示せばわずかな行数で記述され，また実験観 測写真でみてあ非常に簡涛にみえる流れ場ではある が，理論解析の方はそのようにはいかなかった，流れ

*物体に固定した座標系でみた 無限上流からの流れ条件 で，前述の飛行条件と同じ意味をもつ。

***他の等洒は表現で置きかえられることすある. 
場の簡潔な美しさに鬽かれてての問題に立ち向かった 解析的研究はいずれも成功保程遠い結果でしかなかっ た. VAN DYKE はそのの当時までの解析的手法を総点 検し，いずれもの理論が発散や収束の点で問題を抱え

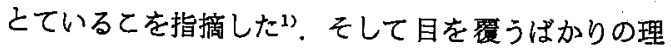
論の貧困さを救う対策として電子計算機による数值厳 密解を求めることを考えた。ちょうどそのころ電算機 が実用化の域に達していたことが動機の一つであった かもしれない，がとにかく一連の軸対称針頭問題の逆

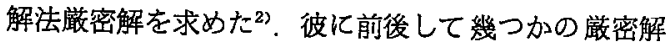
が逆解法で調べられているが，不安定回避対策におけ る差を除けば軌を一にするものであり，徹底さの点で はVAN DYKE に止めをさすといえよう。 そてで逆解 法について簡単な説明を行ない，付随した問題点の幾 つかを指摘しておてう，後の説明の便宜ああるから， 基礎方程式の提示をしておく. 非粘性完全気体の流れ 場は Cartecian $\left(x^{1}, x^{2}, x^{3}\right)$ 座標化扔いて次式に上り 記述される。

$$
\begin{aligned}
& \frac{\partial \rho}{\partial t}+\operatorname{div}(\rho u)=0 \\
& \frac{\partial(\rho u)}{\partial t}+\operatorname{div}(\rho u u+p I)=0 \\
& \frac{\partial E}{\partial t}+\operatorname{div}(u[E+p])=0
\end{aligned}
$$

とこで, $\rho, u, E$ および $p$ は密度, 速度べクトル, 単 位体積あたりの全エネルギー，圧力を表わす．式中の $I$ は単位テンソルを，uuは速度べクトル成分 $\left(u^{1}, u^{2}\right.$, $u^{3}$ ) の dyadic product を意味している. 6 個の未知 量に対し，5個しか式がないので，系を完結されるた 熱状態方程式

$$
p=\rho(\gamma-1) e
$$

が追加されねはならない， $\gamma$ は気体の比熱比， $e$ は熱 エネルギーである. 今は定常流を考えるから(1)式の 時間微分項を落とするのとする. また 2 次元や軸対称 では空間座標 2 個 $\left(x^{1}, x^{2}\right)$ についての div 演算を考 えれぱよい。

まず，衝撃波形状を仮定して，波面が座標面と一致 する座標系を選ふ：との座標系は, 解を求める範囲で よいが，特異点を持ってはならない，てれは解析的衝 撃波形状したがって解析的流れ場を想定したととと同 等である. また特異点が物体内部であるあのは差し支 えないし，変換の Jacobian が 1 であれば直交座標で なくとあよい*，変換された座標空間を $(\xi, \eta)$ とし， $\eta=$ 一定上儿衙撃波面があるすのとしよう. 解かれる べき未知量を代表的に $X(\xi, \eta)$ で書くことにすると，

*目的によっては，とのような座標系を㔍極的に選ぶ文 献 3),4), および5)などう.
変換後の式を適当に代入消去するととにより

$$
X_{\eta}=X_{\eta}\left(\xi, \eta, X, X_{\xi}, g\right)^{*}
$$

の形で $\eta$ 微分を表放すことができる，一方 $X$ の Tay. lor 展開を考えると

$$
X(\xi, \eta+\Delta \eta)=X(\xi, \eta)+\Delta \eta \cdot X_{\eta}+\frac{(\Delta \eta)^{2}}{2} X_{\eta_{\eta}}+
$$

であるから，基礎方程式を用いて得た( 3 )式の $X_{\eta}$ を 代入することにより

$$
X(\xi, \eta+\Delta \eta)=X(\xi, \eta)+\Delta \eta \cdot X_{\eta}
$$

すなわち，打ち切り誤差 $(\Delta \eta)^{2}$ で $\eta$ 方向への計算が 進められる. $X_{\eta}$ 中に含ま机る $X_{\xi}(\xi, \eta)$ は $X(\xi, \eta)$ が わかっていれば，数値微分等などで評価可能である. 実際の計算は， $(\xi, \eta)$ を微小間隔 $(\Delta \xi, \Delta \eta)$ で分割し た格子空間（第 3 図）上で行なわれる。衝撃波面（ $\left.=\eta_{s}\right)$ 上において, $\Delta \xi$ でとの点において, 斜め衝撃波 関係式が解か初期值 $X(j \Delta \xi, \eta s)^{* *}$ を設定する。 そ の後は上記を繰り返し手順とし $\eta$ 方向へ前進計算し物 体表面认達するまで続けられる．物体面到達は境界条 件の充足によって感知される，とはいってあ一般に物 体面之座標面は一致しないから，逆に探し出される． 通常物体内部に突入した格子点上の流れ量は，負の密 度, 速度の符号反転などの異常を示す。乙れが $(k+$ 1) $\Delta \eta$ であったとき， $k \Delta \eta$ に立ち送って，そてから境 界条件が满足されるような $\delta \eta$ ，求める***. こうし て対称面近い方加ら物体形状 $\left(j \Delta \xi, k \Delta \eta+\delta \eta_{j}\right)$ 名 定まってゆく(第3 図)．以上のようにして求められた 物体形状が予定したすのでないならば，衝撃波形状を 選び直して計算を再出発させる．幾回かの試行錯誤的 計算の結果, 許容誤差内で目的形状を得ることができ る. このように書くと，いか似あ簡単そうであるが， 不安定性にたいする回避策が十分であればというただ

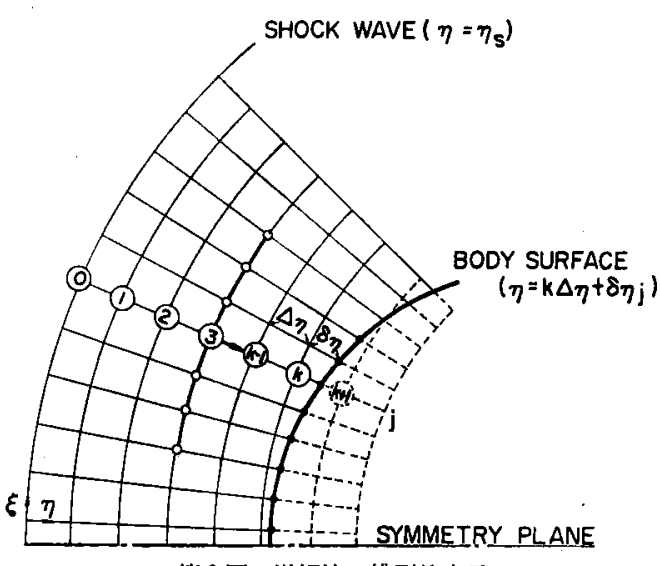

第 3 図 逆解法の模型的表示

\footnotetext{
${ }^{*} g$ は座標変換におけるパラメタで解析的に求められる. ** $j$ および $k$ は整数.

*** 文献4)では，この煩雊さを避けるためクに沿っての流 量を監視する方法が用いられた。
} 
し書きのもとにいい得ることに注意しなければならな い. 数学によれば上記の方法は, 椅円型偏微分方程式 の Cauchy 問題を解くカテゴリに属する.したがって improperly posed であるため, 解の存在に対する初期 值の制約をはじめとして，一意性，収束性に関する本 質的困難を抱えてんでいる. 解の存在や一意性に関し ては，例によって実験との比較で何とか切りぬけるて とにしてあ，収束性は安定な解であることの検証なし には主張し得ないので注意はもっばらこの点に集中さ れる. このため， $(\xi ， \eta)$ 両方向で*の解の単調性を要 請する形での smoothing が行なわれる. このような 微分方程式に根拠をあたない外部的な解の補正は，

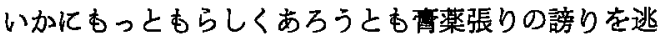
れない，筆者の考えでは，格子刻み幅および差分近似 度を武器としての問題攻撃が再検討されるべきだとす るが，筆者自身それを試みてはいないので，問題点よ して指摘するだけである，とああれ何らかの工夫の あとに，結果的に実験と良好な一致を示す解を得る ことができる，逆解法は安定化操作を含めてあそのア ルゴリズムは比較的簡単であり，計算時間も 1 形状あ たり数分程度である，実際，われわれの身近で得られ た例によれば，軸対称 ( 5 点数值微分， 32 ビット演算， smoothing 無し) で 1 分以下 ${ }^{5 * * *}, 2$ 次元 (7 点微分, 64 ビット， smoothing あり)で2 分以下である***. いわば幾らであ欲するだけの解を生産するととが可能 である.

逆解法にはあう一つの手法があって，GARABEDIAN と LIEBRSTEIN の用いたもので)，複素変数の導入に より問題の移し替えがはかられるあのである。 その概 要は, 物理量 $W(x, y)$ が実(物理)空間での楕円型初 期値問題であるとき，変数の一方を $\left(y=y_{1}+i y_{2}\right)$ の複 素変換により双曲型初期值問題にひきなおすものであ る. このとき初期条件を解析接続しなければならない ので新たな問題を生ずる恐れを除けば棈円型の Cauchy 問題より事情は楽になる。求みられた解のうち $y_{2}=0$ の断面におけるあのが意味をすつ. しかし初期 值か解析的でないと接続困難が起こること，計算時間 が前述の逆解法の 200 倍以上にあなることなどの理由 でほとんど利用されていない．

2 次元でも軸対称でも逆解法がほとんど無力化する のは，平頭円柱のように表面勾配に不連続をあつ物体 形状の発生に対してである. 逆解法において何らかの 形で仮定される解析性のため，てのような形状発生に

*アルゴリズムの简単化のためク方向だけをsmoothing するととが多い。

** HITAC $5020 \mathrm{~F}$ 使用

*** HITAC 5020 による. 第者手持ちのプログラムで計 箕法は3）と同じである.
成功した例を見受けることはできない，また，迎角付 鈍頭物体ではよどみ流線の位置が既知でないなどの 3 次元性のため複输さが增す，流れ状態量の解析性に関 して，比較的強い制約をうける逆解法は攻撃力を失な う度合も強い，比较的小さい迎角の場合だけが僅かに 解かれたにすぎずク ，VAN DYKE 流の解法に做っ たあのは Joss9" に上るあのを見受けることができる 程度である*. 数值解というのはもとあと優雅さの点 では劣るのが当然といっても，対称から非対称問題人 移るときのその失われ方は落差がありすぎる，とあ

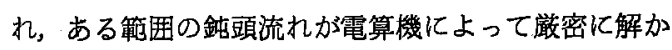
れることが容易になったととは一つの事実として認め ておかねばならない。

このようにして得られた解の結果を，引き続く流れ 領域における境界データとして用いる，その一例は文 献 5）にみられるようなあのとなる，とにかく容易に 解が得られそして現実的にその結果が使用されている てとから，鈍頭問題が解決されたと考えるととは早計 である. 事実次のような厳しい批判が待ちかまえてい る.すなわち，“逆解法は㜟密解を得るのには比較的 簡単な方法で，電算機をむってすれば籗密解を力タ口 グ化するととも可能であろう。しかしてれによって直 接解法に代わり得るとするのは, 空気力学に限らず普 辺的意味でも科学の進歩を迤らせる危険な思想であ る”という内容である ${ }^{10)}$ ．工学的見地からみて，物体 の形を先汇与える直接解法の方が自然な受けいれ易さ をむっていることは事実であるから，この批判は厳し すぎるというものではないと思われる.

VAN DYKE をめぐってのあう一つの話を提供しよ う. 彼は数值厳密解の発表後ふたたび鈍頭問題の检討 を行なった112. その中で，直接解法す含めた数值解法 全体について, “計算はあまりにも個人の洞察力に頼り すぎ，自動化不十分で，流れの単純さに見合わない努 力を強いる点で不成功である。例えば米国の研究所は それぞれが鈍頭の計算プログラムを持ってはいるが， その手法の多様性にみられるように完全に満足してい ない”といった後, “計算を実在気体効果を含む問題 一㹡張するに忙しい”之嗼く，彼の見解は，“計算機 はわれわれを袋小路に追いやり，問題を注意深く考元 させるより算術に向けての飽くなき欲望に委ねさせ る，ゆえに今や以前の解析ないし半解析的手法を再検 討すべき時機”となる．そして収束の蔶困は，その原 因を追究し対策を講ずれば研究に值する理論展開が可 能であるととを示す，彼は，良い理論によれば計算は たかだか常微分を解く程度で斎み，1分以内の機械使

* SWIGART の方法は VAN DYKE のとは思想が異なるが 逆解法である。 
用で事足りる，逆にいえばその程度で現象把握を正確 になし得るのが良い理論であり，そのように志向した 研究を進めるべきであると考えているようである．こ れに対し，後で説明するような時間依存解法を使った BOHACHEVSKY は, “提案されたのは逆解法ばかりで, 迎角付きの場合合理的でないととがある. またその精 度が数值厳密解と比較され，精度収束性が自明でない。 特別な場合についてのみそれらをチェックしてあ一般 性を保証する理由にはならない，そして，機械使用が 15秒であることを強調するが，計算機を 1 分使うか 1 時間使うかのコスト差は200ドルに過ぎないだろう.

誰かが 1 時間計算を短かくするのに 1 年働かねばなら ぬとしたら2万ドルはかかるだろう”などと問を出 す. VAN DYKE は，“簡単な場合にさえ単純な方法が 見つからないとしたら複雑な場合には2万ドルです䭾 目だろう. 私が Garabedian-Lieberstein 法を好まし くないとするのはそれが 3 時間もかかるほど長いため である，ての方法を化学非平衡流住唁すると IBM7094 で 25 時間はかかる. これは長過ぎると考える”, と答えている. 問答に割って入った(?) HAYES は， “現在の計算機は人間よりスマートでない. 解析手法 あるいは良い理論は本質を把える点で計算機より秀れ ている”. とコメントする [以上 11)].

現実は，VAN DYKE の嘆きや反省にもかかわらず 反応流や粘性流への拡張が止まるとてろをしらない勢 いをむってなされてしまったし，今日もなおなされつ つある. VAN DYKE を恐めるような仕事は，非常に まれに，しかあ数值解に気兼ねを意味する言葉を添え てでしかなされない.

ところで，逆解法がなした功績をあげ，それが決し て悪者でないととを指摘しよう. VAN DYKE の仕事 は今日でもなお，その徹底さの故でああるが鈍頭解析 の基準であり，非対称流れのよどみ流線にまつわる 仮説の信恣性を問い指導原理を尊いたのは逆解法であ る*.とのように先導的・開拓的仕事において夢よ再び が失われたとはいえない.

\section{4. 直接解法一-(1) 定常流解析}

偏微分方程式を何引加の近似手段によって常微分に おとせれば, 解を引き出すのはより容易となる. Method of integral relations ${ }^{12-16\rangle}$ と呼ばれるあのは, これを物理的考察に頼りきらないで行なった点が境界 層で馿じみのあのとの差となっている.

（1）式のように保存形式で書かれた場合の一般形 は,

*その他反応性流れ，粘性流への昖張など逆解法のほう が早い時機代試みられている.

$$
\begin{gathered}
\frac{\partial}{\partial x} P_{i}\left(x, y, w_{1}, \cdots, w_{k}\right)+\frac{\partial}{\partial y} Q_{i}\left(x, y, w_{1}, \cdots, w_{k}\right) \\
=F_{i}\left(x, y, w_{1}, \cdots, w_{k}\right)
\end{gathered}
$$

となっている, ててに $i=1,2, \cdots, k$ で $k$ は末知関数 の数である.これらの式を領域

$$
x=0, x=a ; y=0, y=\Delta(x)
$$

において $x$ および $y$ の境界上で $k$ 個ずつ与えられた条 件で解くわけで, $x=0$ を対称 (よでみ) 流線， $y=\Delta(x)$ は衝撃波之対応させればよい， $\Delta(x)$ は既知の境界形 状ではないが，乙こに境界条件を適用させ系を閉じさ せる．また $x=a$ で遭遇する特異性は解の正則性を適 合条件として使用するなどして，境界条件不足あるい は未決定などのためによる不適切さを生じないように する. 次に, ある連続(後に示すように piecewise continuous でむよい) 関数 $g(y)$ を(4)式に乗じ $y$ に関 して積分すると

$$
\begin{aligned}
& \frac{d}{d x} \int_{0}^{\Delta(x)} g(y) P d y-\Delta^{\prime}(x) g(\Delta) P_{\Delta}+g(\Delta) Q_{\Delta} \\
& -g(0) Q_{0}-\int_{0}^{\Delta(x)} Q g^{\prime}(y) d y=\int_{0}^{\Delta(x)} g(y) F d y
\end{aligned}
$$

なる $k$ 個の式（添字 $i$ 省略）が得られる, 式中

$$
P_{d}=\left|P\left[x, y, w_{1}(x, y), \cdots, w_{k}(x, y)\right]\right|_{y=d(x)}
$$

であり， $Q_{\Delta}, Q_{0}$ あ同様の意味をあって定義される. そして，計算領域を

$$
y=y_{n}(x)=\frac{n}{N} \Delta(x) \quad(n=1,2, \cdots, N-1)
$$

ただし， $y_{0}=0$ および $y_{N}=\Delta(x)$

のように $N$ 個の等間隔帯に分割し，とれと対応する $N$ 個の 1 次独立な $g_{n}(y)$ を選び適切な内挿式による $y$ 積分を行なう，その結果，たとえば

$$
\int_{0}^{\Delta(x)} g_{n}(y) P d y \rightarrow \Delta(x) \sum_{n=0}^{N} A_{n} P_{n}(x)
$$

となり近似皘分される． $A_{n}$ は内挿式や $g_{n}$ で決定で きる係数である. 結局, $k$ 個の式を 1 次独立に $N$ 個に 分割し，上記の意味での皘分をしたすのは $(k \times N)$ 個 の $x$ 亿関する連立常微分系になる. 未知関数 $w_{i, n}$ は $k(N+1)$ 個 $(i=1,2, \cdots, k ; n=0,1, \cdots, N)$ であり, $y_{0}, y_{N}$ 上の $k$ 個の境界条件を持つので $x$ 亿関しての 境界条件とともに系を閉じることになる，以上に低触 しないかぎりにおいて， $g_{n}$ と $P_{n}$ は任意に選べる。 し かし問題によって適・不適のあるてとは避けられない。 通常流れ場の状況を予想して選ぶが，結果が思わしく ないときは選び直して再計算するなどの努力がいる. また座標系の選び方す重要である. 物体面と坐標面と の一致, 直交座標系であることなどが要請される.

物体面が $y=0$, 対称面が $x=0$, 衝撃波が $y=\Delta(x)$ と対忘させ， $y$ 程分によって $x$ 亿関する常微分系を得 

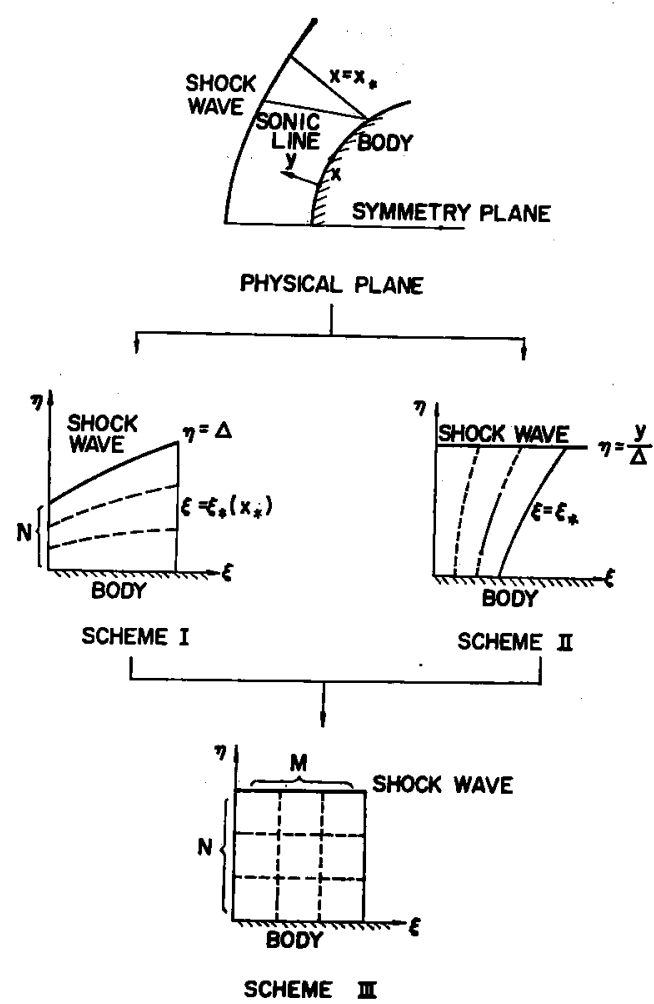

第 4 汹 Method of integral relations におりる各種解 法の模型図

る近似解法は第 1 種と呼ばれる（第 4 図 SCHEME I). このとき $x$ の皘分における特異点(音速線になる) は，解の正則性を要求した適合条件との一致で除去さ れる. $x$ 皘分の初期值（衝撃波踓脱距離： $y_{50}=\Delta(0)$ ) を与えて，音速線で正則性条件が満たされるまで反 復計算される，適合条件を満たす $y_{s 0}$ は精密である 必要がある，つまり解曲線は $y_{s 0}$ 亿敏感であるといえ る. 特異点の性質加らして適合条件の厳密な充足は 不可能であるが，特異点近傍での計算方法（例えば数 值皘分刻みの変更など）の工夫によって消費時間をあ まり増さずに良い精度を得ることあできる． $N=1 の$ 近似においてのての状況の詳細は報告されたものがあ $3^{16)}$. 第 1 種解法は一梯流、ッ八数が大きいほど低い 近似で斎む，すなわち収束性が良くなる．収束が高次 近似解との比較で自己検查できることは良いことでは あるが，それが数值的であること，近似度 1 段上昇によ る困難の增加が近似度倍以上の負担になることなどで 完全な検証はむずかしい，マッ八数が低いほど，そし て当然のととながら軸対称よりは 2 次元流のほうが事 情は悪くなる. マッ八数 3 の円柱まわり流れでは $N=$ 3までやってす有効数字 3 桁がようやく一致するかど うかの程度である ${ }^{15)}$. したがって衙撃層が厚い流れで は別な (例えば後に述へる第 3 種) 解法か推奖される.
第 1 種解法は衝撃層に沿って帯分割を行なった。 と れに対して吿撃層を横切る帯分割も可能である，との とき $\eta=y / \Delta(x)$ の上うな変換で衝擊波物体面が平行 になるようにすると便利である，乙れを第 2 種解法と いう（第 4 図 SCHEME II）。この近似解法では，衝 撃波と物体形状は離散的にしか定められないか，第 1 種に付随した特異性は消去される，ただし境界值（衝 撃波と物体面上でそれぞれ $N+1$ 個）問題が起きてい ることになる．解法の体系からみて第1種よりはアル ゴリズムが簡単となるため, 高次近似の負荷は楽にな っている．流れ場としては衝撃層に沿ってよりあ，そ れを横切っての状態变化が大きいあのに適しているて とは明らかである. 収束性は近似度 $N$ の增加につれ 確実に良好となることも確かである。文献 ${ }^{15}$ では， 、 ッ八数 10 に利ける球まわりの計算について，ての事 情を物語る数表がみられる。

衝撃層の両方向に帯分割をし近似皘分を行なえば， その最終形は連立超越方程式となり数值皘分を含まな い解法を構成できる．乙れは第 3 種解法之呼ばれ（第 4 図 SCHEME III)，衝撃波物体面間距離が大きく第 1 種や 2 種解法では不満足な流れ場に適用して効果が ある. 文献 ${ }^{157}$ には，マッ八数 $1.05 \sim 2.0$ の球まわりの 計算結果が紹介されている。 ての上うな低超音速流れ は第 1 種や 2 種あるいは逆解法で不得手な対象であっ た. ただ第 3 種解法は原理的にみて他の 2 つの解法よ り精度は落ちるので，必然的に高次近似まで解かなけ ればならない，しかし iterationの収束は比較的良好 なので計算時間の負担はさほど重くはならない15)。 ま た第 3 種解法は初めの近似皘分を第 1 種または第 2 種 のいずれにするかで解法構成が異なる，すなわちアル ゴリズムが変わるしそれによる精度す変化するわけで あるが，てれらを比較検討した資料を見るととはでき ない，他の解法，例えば第 1 種法との比較がマッ八数 10の球まわりの流れについてなされている ${ }^{15}$. 第 1 種 法の $N=2$ の解との比較が第 3 種法の $N=2 \sim 5$ につ いてなされている*が $3 \%$ 程度の誤差がある.

Method of integral relations による計算法の原理 はン連の DORODNITSYN ${ }^{17) * *}$ 亿負う。その故ああって かソ連における仕事が最も組織的であり執拗ともいえ るほどである，逆解法と同様反応性流れなどへの拡張 あ盛んに行なわれてきた，しかしてれが直接解法に属

* 沺撃層を横切る方向で 2 分割, それに沿う方向で $N$ 分 割され，第 1 種法を第 1 近做にとった場合.

** DoRODNITSYN および BELOTSERKovskII の論文に関し ては，筆者か入手したものだけを揭げておく．後の著 者関しては標題からみて内容はあまり変わらないだ ろうと思われるが他の場所で古い年代敒表されたも のあある. それらについては, 10), 12)，13)，およひ 15）を参照されたい. 
するためか逆解法のような風当たりの強さはあまりな い:だが批判の無いことは何をしてあよいというライ センスでないことは確かである：たとえば，迎角付き 鈍頭流れにおいてよどみ流線に仮定をおいてなされた 解析では逆解法の勝利によって生き残れなかったすの が出ている。

この解法は表面曲率不連続や非対称物体まわりの流 れに対し，逆解法ほどでないにしろ急激化精彩を失っ てくる. そこでの解法は泥具さが目だち始め力で押す 印象を残す。てれらを取り除くことが大きな課題とな るであろう，ソ連の組織力と執念潹さをあってすれば 片付くことであるかあしれない．この方法に限らない が鈍頭解析に関するソ連の仕事の紹介が文献 18) にみ られる。

直接解法による厳密解はわれわれの国においても試 みられた ${ }^{199}$ ．乙の解法は上述のようなあのと比較する と，計算機と相性のよくないととがある，しかし，今 日のように大型高速でかつ豊富な I/O 機器をあつ計算 機にとってそれほどのあではない，上筆者は考えてい る. 論理的厳密性を具備したての解法がわれわれの国 において無関心のまま過されているのは残念なととの ように思われる. Method of integral relations にお ける BELOTSERKOVSKII 一派の仕事をみるにつけ，筆 者自身の反省も加えて，いつかは検討が試みられるて とが必要であると考えている.

\section{5. 直接解法一(2) 時間依存解析}

偏微分方程式を差分近似で解くととは目新らしいと とではない.しかし,差分解法が現実性を高めたのは電 子計算機の大型高速化による一つの結果であるし，そ の数学的基礎が充実してきたためであある，逆解法で 用いられた差分解法が数学的にあまり明らかに説明さ れていないのに比較すれば，以下に述へる時間依存解 法は幾分か優位の上うに思われる。といってあ，アルゴ リズムの中核となる差分法そのむのについてだけであ って, 解法全体として系統つけられた理論の支配下に あるのではない。とくに初期值境界值混合問題の差分 法は支配する強力な理論か欠けているから，鈍頭に限 らず多くの流体力学の問題において共通して言える注 意である。時間依存解法は名のとおり時間に関して解 かれ，その基礎方程式は（1）式そのあのになる.それが 非定常流解析之呼ばれないのは，風胴実験や実聝にお ける定常流の成立過程とは異なった仮想的初期条件を 使うため, 非定常 $\rightarrow$ 定常への力学的緩和現象として途 中の結果を理解しにくいためであろうと思われる。 ちろん，そのように䍐実的な初期条件のむとに解けな いわけではないが，計算時間が多くなり過ぎるため，
非定常楥和の解析が目的でないかぎり用いられない．

このカテゴリに属する計算法は大別して，基礎方程 式を厳密に差分化するもの上，何らかの流体粒子模型 化を行なったのち差分化するすのとに区別するととが できる．前者の方法牥数学のみを武器とするから厳密 性の信頼感が高く，後者の方法は直観的な理解のしや すさで秀れている，乙れらについては解説が出されて いる200ので，ててではそれを繰り返さないが，前者の 手法で著者にも経験があるものを代表として簡単住説 明しておてう。

(1)式のように保存形式に書かれた方程式はそれぞ れ時間微分と空間微分がひとかたまりになっているの で, ベクトル値関数表示によって

$$
w_{t}=f^{i} x^{i}
$$

と書いてしまうことができる。 $w$ は transposed して $\left(\rho, \rho u^{1}, \rho u^{2}, \rho u^{3}, E\right)$ を成分とし， $f$ は $w$ の非線形 関数で $w$ に対応する成分をすつ， $t$ と $x^{i}$ は時間およ び $x^{i}(i=1,2,3)$ 空間偏微分の意味である. 簡単のた め空間 1 次元流れを考える， $x^{1}=x, u^{1}=u$ などとして

$$
w_{t}=f_{x}
$$

$$
\begin{aligned}
& \text { ただし, } w^{T}(\rho, \rho u, E) ; f^{T}\left(-\rho u,-\left[\rho u^{2}+p\right]\right. \text {, } \\
& -u[E+p])
\end{aligned}
$$

である. pは(2)式に示したとおり，またこの場合

$$
E=\rho\left(e+\frac{1}{2} u^{2}\right)
$$

であって系は完結している，wを Taylor 展開すると

$$
\begin{aligned}
& w(t+\Delta t)=w(t)+\Delta t \cdot w_{t}(t) \\
& \quad+\frac{\Delta t^{2}}{2} w_{t i}(t)+\frac{\Delta t^{3}}{6} w_{t u}(t)+\cdots
\end{aligned}
$$

であるから，何らかの方法で $w_{t}, w_{t}, \cdots$ などを評価 すれば，その段階までの精度をもって $w(t+\Delta t)$ を求 めるととができる. 基礎方程式 (6)は明らかに が $f_{x}(t)$ の空間微分をむって評価できるととを示して おり,したがって

$$
w(t+\Delta t)=w(t)+\Delta t \cdot f_{x}(t)
$$

としたすのは打ち切り誤差 $O\left(\Delta t^{2}\right)$ の精度にある差分 を与えることができる。

さらに $f$ がwの微分を含んでいないとと着目して $w_{t}=\left(f_{x}\right)_{t}=\left(f_{w} w_{t}\right)_{x}=\left(f_{\mathrm{w}} f_{z}\right)_{x}$

と評価できるから

$$
w(t+\Delta t)=w(t)+\Delta t \cdot f_{x}(t)+\frac{\Delta t^{2}}{2}\left(f_{w} f_{x}\right)_{x}
$$

という形式で，誤差 $O\left(\Delta t^{3}\right)$ の差分法を得られるとと あ容易に理解できる，上式中 $f_{w}$ は， この場合， $3 \times 3$ の行列*になるが, w( $(t, x)$ を用いて值ちに値が求めら

*この固有値 3 個がともに実数であるととで（6)式は 双曲型惼微分方程式であるととが示される。 
れる. この評価法によるものは LAX-WENDROFF ${ }^{21)} ら$ が考え，多くの人々によって実用計算が試みられ信頼 性が高められてきている，差分式の具体的表現および 計算例を報告でみることができる22．

打ち切り啌差 $O\left(\Delta t^{4}\right)$ 以上の差分法は LAX-WENDROFF 流の考え方では困難がある，そこでは $f_{\mathrm{w}}$ の微 分が必要となりその評価に self-consistentなものを見 つけ難いためである*. それで RICHTMYER ${ }^{23)}$ が提案 したような逐次近似法が有效性を発揮してくる，との 方法は，常砫分に括ける RUNGE-KUTTA の思想を採 用したあのとみることができる、RUNGE-KUTTAのと きと同様に $r$ 回目反復公式を

$$
w^{(r)}=w^{(0)}+\Delta t \sum_{s=0}^{r-1} \alpha_{r s} f_{x}^{(s)}, \quad r=1,2, \cdots, k
$$

と書き, $k$ 回目に $w(t+\Delta t)$ を求めるように解法满成 を行なう. このとき $f^{(s)}$ は $t=t_{0}+\tau s \Delta t \quad(s=0,1, \cdots$, $k-1)$ の各レベルでの値であり， $\tau_{0}=0, w^{(k)}=w(t+$ $\Delta t)$ および $w^{(0)}=w(t)$ などとする，例えば $k=2$ と おいて

$$
\begin{aligned}
& w^{(1)} \equiv w\left(t+\tau_{1} \Delta t\right)=w(t) \alpha_{10} \cdot \Delta t \cdot f_{x}(t) \\
& w(t+\Delta t)=w(t)+\left\{\alpha_{20} f_{x}(t)\right. \\
& \left.\quad+\alpha_{21} f_{x}\left(t+\tau_{1} \Delta t\right)\right\} \Delta t
\end{aligned}
$$

が得られる. まず上の式によって $w\left(t+\tau_{1} \Delta t\right)$ を求め,

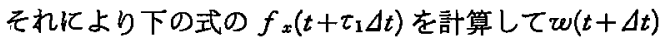
を得ることになる，荷重係数 $\alpha_{r s}$ は $w^{(s)}$ の Taylor 展開

$$
\begin{gathered}
w^{(s)}=w+\tau_{s} \cdot \Delta t \cdot w_{t}+\frac{\left(\tau_{s} \Delta t\right)^{2}}{2} w_{u}+\cdots \\
=w+\tau_{s} \cdot \Delta t \cdot f_{x}+\frac{\left(\tau_{s} \Delta t\right)^{2}}{2} f_{x t}+\cdots
\end{gathered}
$$

を各必要精度まで比較し決定するととができる，上例 の場合

$$
\alpha_{10}=\tau_{1}, \quad \alpha_{20}+\alpha_{21}=1, \quad \alpha_{21} \tau_{1}=\frac{1}{2}
$$

であって，1パラメタ でををえることにより $\alpha_{r s}$ が 決定される， $\tau_{1}=1$ または $1 / 2$ とした 2 通りの差分法 が紹介され，比較検討されている22. これは打ち切り 运差 $O\left(\Delta t^{3}\right)$ のあので LAX-WENDROFF のあのと等価 である. 同様な手順を繰り返すととにより打ち切り諤 差 $O\left(\Delta t^{4}\right)$ の差分法が RuSANOV ${ }^{24)}$ および BURSTEIN ら25) によって導加てている.

空間次元が增した場合であ，ここに紹介した 1 次元 の手順を繰り返すことにより必要な差分法を展開する ことができる. $O\left(\Delta t^{5}\right)$ の打ち切り誤差をもった差分法 の完成もそう遠いととではあるまいから，少なくも原 理的に常微分に較ぺて, そんなに磻色を持つようなと

* 特別なに $f$ ついては可能であるが，それは数学的興味 の双曲型偏微分方程式でる。
となく偏微分の数值解が得られると考えてよい.

ここに紹介したあのばからりでなく，とこでのカテゴ リに属する計算法の大部分が持っている大きな特徽 は，流れ場の中に存在する不連続面あるいは極限線を 境界面として特別报いしないで斉むととである，衝幹 波のような不連絸面を横切って計算する場合であ，そ こに衛搫波面が存在するととによって流れ場を分割し なりればならないというようなととは起とさないで斉 む. 差分法の打ち切り誤差項が散逸的であるような工 夫，あるいは衝撃波面通過のような状態変化の大きい ところでは効くが他の比較的滑らかな流れ場のところ では打ち切り啌差項程度に落ちてしまうような人工粘 性項の工夫などによってとれが可能になる．また極限 線にも無関心でいられるととは，亜音速から超音速ま でを含む流れ場でも全く一種類のアルゴリズムで一気 に解けるととを意味している．したがって迎角を持つ 場合でも，勾配不連続を持つ物体でも，ひたすら空間格 子の各点で同じ計算を繰り返しさえすればよい，この 馬鹿みたいな手法は自動化の点で全く計算機むきであ る.それだけに，不用意に使うと計算譏と力較べをして しまうことあ起こる. たとえば，空間分解能 1/100を 要求した計算を行なうとしよう．差分法の最大安定条 件の下で衙撃波が 2 の の格子点幅で表現されるこ上 から，少なくも 1 座標方向 200 個の格子点, 空間座標 が 2 個なら 40,000 個の格子点が必要である. この場 合，流れ状態量 4 個が各点で記憶されていなりればな らないから，総計 160,000 個の記憶用領域が入用とな る. 1 語長演算としてす 160k 語を rapid access memmory* で確保できるような計算機はそうざらにはな い. このため補助記憶媒体を使うことになるが，乙れ が計算に著しい目担をもたらす，筆者の属する研究所 の計算機 (HITAC 5020 F) システムに,この例をあて はめてみよう.ユーザ・エリア $55 \mathrm{k}$ 語のこの計算機で は $160 \mathrm{k}$ 語の $1 / 3$ をコアで確保するのが精一杯である から， $\Delta t 1$ 回につき 3 度媒体亡データ受授を行なうこ とになる，磁気ドラムを媒体に選ぶとしてあコアセド ラムのブロック・データ輸送に $2,027 \mathrm{msec**,} \mathrm{アクセ}$ ス $20 \mathrm{msec}$ を含めると $2,047 \mathrm{msec} の$ 間はコア・デー タに手をつけるような作業(差分計算)ができない***. とうし $\Delta t$ ごとに 6 愁強，乙の種の計算の通常の繰 り返し回数 $1,000 \Delta t$ では 6,141 秒にも達する.

筆者が用いるような差分演算では 1 格子点あたりの ステップが 860 ほどあり，乙の計算機のギブンン・ミ クス値 $1.9 \mu \mathrm{sec}$ によれば 1 点あたり $1.63 \mathrm{msec}$, 全格

*通常コア・メモリと呼ばれる領域をさす。

**. $2 / 3 \times 160(\mathrm{~kW}) \times 19(\mu \mathrm{sec} / \mathrm{W})$

***媒体が磁気ディスクではほほ 1 桁悪く，磁気テープを 使うのはほとんどナンセンスに近い。 
子数 40,000では 65 秒ほどであるから，上記のような 転送待ち時間はフラクションとしてみても無視できな い.とれらは高速機になるほど大きな問題であり*, この種の計算には高速かつ大型(コア容量)機でなけれ ば経济性の儀牲を強いた力較べの印象がましてくる。

話を元へ戾して,とのカテゴリの計算実例を示そう. アポロ・カプセルによく似た鈍頭物体の例がある ${ }^{26)}$.

(7) 式による LAX の差分法が球面極座系に机いて適 用された。物体形状および計算領域などのスケッチを 第 5 図に示しておく，空間格子は紷計 24,000 点であ るから，5個の流れ量を保存するため $120 \mathrm{k}$ 語の記憶 場所がいる. 使用した計算機が IBM 7044であったか ら，媒体として磁気テープが使われ定常流到達まで 150 回の繰り返し計算がなされた。 その所要時間はデ イバックも含めて 15 時間であった ${ }^{26)}$.

てのほか鈍頭の計算は LAX-WENDROFF によるも

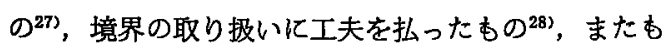
う少し違う原理によるもの 29 ,30)など，代表的にみただ けであかなり試みられてきた。 その多くは数時間程度 の占有時間を必要とするものである. このた計算機 に対して，上り速く，上り大容量を要求する声が上が り，現状への不満を語るてとは当然とされているかの ようである. しかし，との種の解法の先覚者である RICHTMYER が, “計算機の不適当さよりは数学的方法 の不適当さによる制約の方が大きい，問題の特異性な どの性啠を良く知り，適切な公式化汇持ち迈むよう工 夫する必要がある”とたしなめている言葉 31 を味わい 直すことは重要である.

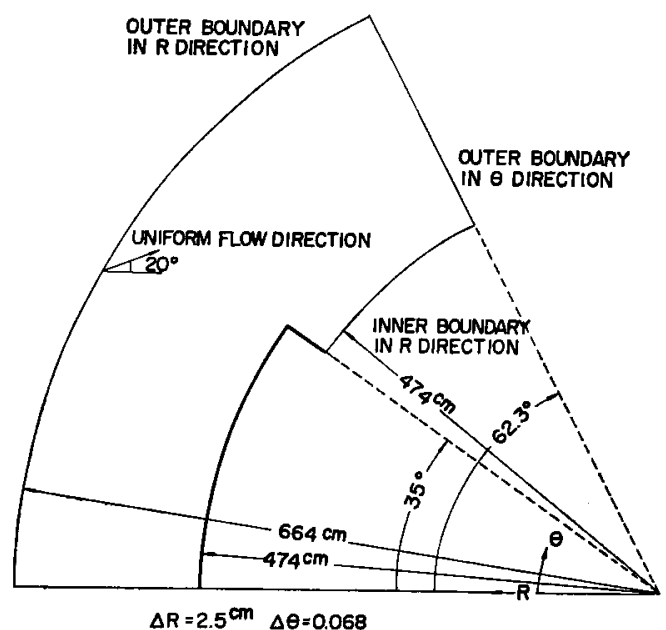

第 5 図 迎角つき鈍顽物体まわりの流九における計算領域 球面極座標系におりる $\varphi=0$ 面を示す. $\varphi$ 方向は $6^{\circ}$ 間 隔で格子面を切ってある $(\varphi=0 \sim \pi)$.

* 昭和 47 年後期はに国産機でもギブソンミクス值 0.2 $\mu \sec$ 程度のものが運転されるがドラムやディスクの 性能はあまり変わらない.
計算機自体は量子物性工学の進歩とともにまだ早く なりうる余地を持っているし，原理的には $1,000 \mathrm{~kW}$ 程度のコア・メモリを制御する機械を作るのも容易で ある. また設計概念を変えるととにより巨視的にあっ と早い計算機す出現している。 こてで述べような計 算では ILLIAC IV が独走的優位性を発揮する．乙の 機械は 64 個の独立した処理装置を持っており,一つ の処理装寘の性能はそんなにすばらしいものではない が，これらの処理装置が並列運転されることにより驚 くべき速さをみせる*．今の場合のような差分計算で は，格子点を順次に追って演算を繰り返さなりればな らないというアルゴリズムをあったものは少なく，ど てからまた何個所から手をつけ始めても差し支えない あのの方が多い．だから同じ計算でも ILLIAC IV に まかせれば，大ざっぱにいって 64 倍の速さで答を出 してくれると期待できる．こうして 100 時間を要した 計算です 1 時間そとそこのあのになってしまうことに より，輸送過程を含むような複雑な流れでも数値解析 の現実性が鬲められる．このようにして，時間依存解 法は流れをシミニレートするという言葉に似つかわし い手法のように思われる，しかし，筆者はこの解法が 定常問題の解析に利用され勝ちな点に不满を持ってい る. この解法が本来他の解法の守備筙囲でないとてろ において活細しててそ流れのシミュレートに䎵じない 内容をもつといいたいのである. とはあれ，乙の解法 の有用性が增してくるととは事実であろう，そのとき われわれが持つべき不満はわれわれの側化ある機械へ の頼り過ぎにあると考える. あっと多くの手法が考え られ，ためされるべきであろう. そのようなととで， との解法は始まったばかりといって差し支えない，吹 き出しをもつ鈍頭物体 ${ }^{33}$ ， 円柱まわりの衛熬波回折 ${ }^{34)}$ などの複雑な流れの解析あわれわれの国で行なわれ始 めた.

\section{6. むすひ}

鈍頭問題という流体力学の局所的場面をとらえて, 流れの解析がどのようにして行なわれるかの方法論の 概略とそれがどのような目でみつめられているかを示 す素材を提供したつありである. とのようなわずかば かりの問題においても筆者の経験は不十分で, とうて い物事を断定的に述へる勇気は無い，ただ，かなりな 計算時間を使った経験を持つ者の一人として，作業過 程の中で考えてきたことを誌して結びとさせていただ きたい.

実駘と計算との対比論としてよくいわれるととがあ

*との結果ギブソン・ミクス值換算 $5 n \mathrm{sec}$ 相当の処理 速度が得られている(文献 32). 
る.それは，実験は設诵が無ければならず誰にでも使 えるというすのではない，人手すいる，またあらゆる 条件を実験室実験では再現できないし，研究者の個性 や能力あるいは経験によって良いデータを出さないと いう意地悪さがあると，対比論は立場があってなされ ると危険を自ら招くことにあなる．上記のは計算の㑡 からであるのは明らかで，それをいい得る条件の確保 なしに大きな声で主張してはならないすのである。 ず，何といってあ計算機からでてくる数字は現象自身 ではない点があげられる. 予想をこえた結果の出見と いうことは計算です実験です起こりうることである が, 計算の結果の場合, そのような事態の発生に対し て因果関係を求めて物理的説明をほどてそうとしてす 無䭾である. 計算機にはこの世のものではないことで あ，何食わぬ顔をして出てくる意地悪さがある，それ を見分けるととができないと計算機に愚弄されてしま う. 㴞々と語られた計算結果が，注意深い追試者によ って単なる桁落ちの結果であったという指摘を受けた 実例がある，これなどは指摘された研究における計算 技術の低さが嘲笑されたにとよ゙まらず，背景となった 理論への理解度が疑われたと受けとめるべきである. たとえ理論が十分に理解されていても，これと大同小 異の事態を引き起てす危険性を計算機は持っている. その素張らしい速さの故に計算過程の一つ一つを監視 しているわけにはゆかない，手計算であればそれほよ゙ 注意深くなくとあ⿹气㐅乂付いたであろうような簡単な事で すら見逃されることあある，多くの場合，異常結果は 胸ときめかす新事実の発見ではなくて，自らの経験か 注意の不足の発見に終わる。

計算技術と関係して，あう一つ指摘を行ないたいて とがある.それは手計算であれば到底やらないよう な事が平然とプログラムされているということであ る、それは，たとえば 2 で割る 10 で割る，あるいは 定数計算といった類の細かいととやら，零要素の多い 行列演算など初等的なととから始まって種々の事柄が ある．要するに手計算であれば耐え難いようなととが 平然と繰り返される，しかあ特別な目的無しにという 点である．筆者はそのようなプログラムを見ると必ら ずアレルギーを起てす. そこでは人智の進歩の面影は 何も無く，計算機の速さにどっぷりとひたった怠惰が 目につくからである. 確かに計算機は速く，そして第 4 世代に向けて 1 桁以上の速さ上昇がみられそうであ る. われわれはその速さに見合う感覚をむって物事を 見つるるべきで，上記のようなととについて（多少の ムダはというような) 日常生活の感覚での判断は, 速 さの進歩の故にもたらされる人智の退歩への前兆と受 けとめるのは考え過ぎであろうか. 一事が万事という
こともある．そのような感覚がもっと本質的で重要な こと，研究の phylosophy にまで染みついてしまった ら全ては終わりである.

計算機は正しい手続きで頼みさえすれば，いくらで も仕事を引き受けてくれ，倦むととを知らない.とうし た気楽さに馿れ過ぎると，山と皘まれた結果の前で人 間は溜息をつくばかりという根性悪なととろあある。 計算機が作られ，そして進歩をしたがために起こる滑 嵇㺂の実例は幾らもある，そうした場面において，計 算計画の悪さを笑うことで斉まない別の問題がある.

工学の研究の立場にあるかきり，計算機の利用を研 究の phylosophy と切り離して考えることはできな い. それは実験においてあ同様である，批判されるす のは研究の基礎におかれている phylosophy であって 結果の合法性を争うだけで判断することは誤りである といえよう、いつのころからか, 実験家・理論家という 区別があらわれて，現象観察という根本を忘れたとと ろへ議論を持ちとむ危機を生じかけた，近でろは，ま たひとつ計算家なるすのが出てきて，数值実験などと いうことを始め，あう一つの核化が起こりそうでああ る.このような事態において,そして本シンポジムの 課題に答えて，それぞれが相補性をもって工学の進步 に奇与すべきだという心地良い言葉を使いたくない気 持である. それが必然的結論として得られるだけの経 過をわれわれが踏んではいないと考えるからである.

\section{参考文献}

1) van Dyke, M.D.: The Supersonic Blunt-Body Problem-Review and Extension, JASS, 25, 1958, pp. $485-496$.

2) van Dyke, M.D. and Gordon H. D.: Supersonic Flow Past a Family of Blunt Axisymmetric Bodies, NASA TR R-1, 1959.

3) Fuller, F. B.: Numerical Solutions for Supersonic Flow of an Ideal Gas Around Blunt TwoDimensional Bodies, NASA TN D-791, 1961.

4) 安喜隆幸：蚛頭物体の先端付近におりる非平衡流，日 本航空学会誌，第 13 巻，第 140 号, 昭和 40 年 9 月.

5）河本㒈：鈍い頭部を有する円筒物体まわりの超音速流 れ，航空宇宙技術研究所報告 TR-199，昭和 45 年 6 月.

6) Garabedian, P.R. and Lieberstein, H. M.: On the Numerical Calculation of Detached Bow Shock Waves in Hypersonic Flow, J.A.S, 25, 1958, pp. 109-118.

7) Swigart, R. : A Theory of Asymmetric Hypersonic Blunt-Body Flows, AIAA J. 1, 1963, pp. 1034-1042.

8) Swigart, R. : Hypersonic Blunt-Body Flow Fields at Angle of Attack, AIAAJ. 2, 1964, pp. 115-117.

9) Joss, W. W. : Application of the Inverse Technique to the Flow Over a Blunt Body at Angle of Attack, NASA CR-445, 1966.

10) Hays, W. D. and Probstein, R.F.: Hypersonic Flow Theory, 2 nd. ed., Vol. 1, Inviscid Flows, 
Academic Press, 1966, pp. 391-479.

11) van Dyke, M. D.: The Blunt-Body Problem Revisited, in Proc. Intenatl. Symp. on Fundamental Phenomena in Hypersonic Flow, J.G. Hall, ed., Cornell Univ. Press, 1966. pp. 52-65.

12) Belorserkovskiy, O.M. and Chushin, P. I. : The Numerical Method of Integral Solutions, NASA TT F-8356, 1963.

13) Belotserkovskit, O.M. and Chushrin, P. I.: The Numerical Solution of Problems in Gas Dynamics, in Basic Developments in Fluid Dynamics, Vol. 1, M. Holt, ed., Academic Press, 1965.

14) Belotserkovski, O. M., Bulekbaev, A. and GrudNITSKII, V. G. : Algorithms for Numerical Schemes of Method of Integral Relations for Calculating Mixed Gas Flows, U. S. S. R. Comp. Math. Math. Phys., Vol. 6, No. 6, 1966, pp. 162-184.

15) Belotserkovski, O. M. ed. : Supersonic Gas Flow Around Blunt Bodies, NASA TT F-453, 1967.

16) 神元五郎, 石井隆次：Method of Integral Relations に上る鈍頭物体まわりの流れの研究，日本航空宇宙学 会誌，第 17 巻，第 185 号，弨和 44 年 6 月.

17) Dorodnitsyn, A. A. : A Contribution to the Solution of Mixed Problems of Transonic Aerodynamics, in Advances in Aeronautical Sciences, Vol. 2, Pergamon, 1959, pp. 832-843.

18) Belotserkovskin, O.M.: Numerical Methods of Some Transonic Aerodynamics Problem, J. Comp. Phys. 5, 1970, pp. 587-611.

19) Uchida, S. and Yasuhara, M.: The Rotational Field Behind Curved Shock Wave Calculated by the Method of Flux Analysis, JAS., 23, 1956. pp. 830-845.

20) 里深信行：王縮性流体力学におりる数値計算，日本航 空宇䡒学会誌, 第 18 巻, 第 197 号, 昭和 45 年 6 月.

21) Lax, P. D. and Wendroff, B.: Systems of Conservation Laws, Comm, Pure Appl. Math., 13. 1960, pp. 217-237.

22）安喜隆幸：人工粘性付 LAX-WRNDROFF およびその変
形差分法関する数値実験，航空宇宙技術研究所報告 $\mathrm{TR}-217$ ，昭和 45 年 9 月.

23) Richtmger, R.D.: A Survey of Difference Methods for Non-Steady Fluid Dynamics, NCAR TN 63-2, 1963.

24) Rusanov, V. V., : On Difference Schemes of Third Order Accuracy for Nonlinear Hyperbolic Systems, J. Comp. Phys. 5, 1920, pp. 507-576.

25) Burstein, S.Z. and Mirin, A: A.: Third Order Difference Schemes for Hyperbolic Equations, J. Comp. Phys. 5, 1970, pp. 547-571.

26) Bohachevsk y, I. O., Rubin, E. L., and Mates, R.E. : A Direct Method for Computation of Nonequilibrium Flows with Detached shock Waves. I. Two Dimensional Flows, AIAAJ. 4, 1966, pp. 600-607, II. Axisymmetric Blunt-Body at an Angle of Attack, ibid, pp. 776-782., also AIAA paper No. 65-24, and also NASA CR-483, 1966.

27) Burstern, S.Z., : Finite-Difference Calculations for Hydrodynamic Flows Containing Discontinuities, J. Comp. Phys. 2, 1967, pp. 198-222.

28) LApidus, A.: A Detached Shock Calculation by Second-Order Finite Differences, J. Comp. Phys. 2, 1967, pp. 154-177.

29) Moretti, G. and Abeert, M. : A Time-Dependent Computational Method for Blunt Body Flows, AIAA J. 4, 1966, pp. 2136-2141.

30) Moretti, G. and Bleich, G.: Three-Dimensionel Flow Around Blunt Bodies, AIAAJ, 5, 1967, pp. 1557-1562.

31) Richtmyer, R. D. and Morton, K. W. : Difference Methods for Initial-Value Problems, Wiley, 1967.

32) Slotnik, D. L.: The Fastest Computer, Scientific American, 224, No. 2, 1971, pp. 76-87.

33) 広瀬直喜: 空気力学的諸問題の非定常差分法に上る数 値計算の研究，東京大学学位諭文，昭和 46 年3 月.

34）安喜隆幸：円柱まわりの偛缼波回析，第 1 回および第 2 回流体力学講演会予稿集.

\title{
モンテ・カルロ法の応用* \\ Application of Monte Carlo Method
}

\author{
古浦 勝 久**
}

高速大容量の計算機の出現により, 理論式の数值解 を求める通常の方法とは異質な，数值実駼が可能侸な っている. 数值実験は問題の素過程の設定とその生起 に対する仮定により，計算機で菜過程を多数回生起さ 甘必要な情報を得る．装過程の設定とその生起の仮定 は理論および実験室実験によって検証される。モンテ ・カル口法は素過程の生起の仮定に確舜論的モデルを 用いる場合の数值実験法である.

\footnotetext{
* 昭和 46 年 9 . 2 日原稿受理
}

** 航空宇秞技術研究所
数值実験は㖕算機の性能に大きく依存するため, 現 在の計算機では限られた問題にのみ可能である. しか し，NASA に书けるIlliac IV のような新システム による高速大容量計算機の出現は, 数值実験の效率化 ととあに，数值実験の可能な範囲を大きく拡張するて とが期待される。

数値実験は次の場合に有効である.

(1) 理論, 実験室実験ともに存在しない問題

(2) 実験室実験の存在しない問題

（3）理諭の存在しない問題，および存在しても通 